\title{
A NOVEL SENSITIVE AND SELECTIVE POTENTIOMETRIC SENSOR FOR RISPERIDONE DETECTION
}

\author{
OMER ISILDAK $^{1 *}$, AYSENUR BIRINCI $^{1}$ \\ ${ }^{I}$ Gaziosmanpasa University, Faculty of Science and Education, Department of Chemistry, Tokat, Turkey \\ *corresponding author: omer.isildak@gop.edu.tr \\ Manuscript received: September 2016
}

\begin{abstract}
An antipsychotic drug containing risperidone can be analysed by liquid chromatographic techniques (LC) using UV-visible and fluorescence detectors. However, all developed methods based on LC are expensive, time consuming due to pre-and post-column reaction, and also not very sensitive. The preparation of micro-sized composite risperidone-sensitive sensors and their suitability as detector in a flow-injection analysis system is described. A risperidone-sensitive sensor membrane was prepared by coating a composite cocktail on the surface of the contact transducer in solid state. The composition ratio percentage for the best performance was obtained with $2.5 \%(\mathrm{w} / \mathrm{w})$ active ingredient (ionophore), $67 \%(\mathrm{w} / \mathrm{w})$ plasticizer, $30 \%(\mathrm{w} / \mathrm{w}) \mathrm{PVC}$, and $0.5 \%$ sodium tetraphenyl borate. The potentiometric performances of risperidone-selective sensor (selectivity constant, liner domain, detection limit, response time, $\mathrm{pH}$ working domain, repeatability, lifetime, and time dependent potential decay) were determined using computer controlled measurement systems in static conditions.
\end{abstract}

\section{Rezumat}

Medicamentele antipsohotice cu risperidonă pot fi analizate prin tehnici lichid cromatografice (LC), folosind detectori UVVizibil şi de fluorescenţă, dar toate metodele LC descrise în literatura de specialitate nu sunt suficient de selective și/sau sensibile, sunt costisitoare şi consumatoare de timp din cauza reacţiilor pre- și post-coloană. Prin urmare, s-a abordat obţinerea unor microsenzori risperidonă-selectivi şi utilizarea acestora ca detectori într-un sistem de analiză prin injecţie în flux. Prepararea unei membrane risperidonă-selectivă a fost realizată prin acoperirea suprafaței traductorului de contact în stare solidă cu un amestec compozit. Cele mai bune performanţe au fost obţinute pentru următoarea compoziție: ingredient activ (ionofor) 2,5\% (g/g), plastifiant 67\% (g/g), din PVC 30\% (g/g) și tetrafenil borat de sodiu 0,5\%. Performanțele analitice ale senzorului risperidonă-selectiv (constanta de selectivitate, domeniu liniar, limita de detecție, timpul de răspuns, pH-ul de lucru, repetabilitatea, durata de viață) şi de potențial de degradare timp dependent) au fost determinate în regim static cu ajutorul sistemelor de măsurare asistate de calculator.

Keywords: Potentiometric sensor, risperidone, phenol red, brome phenol blue, PVC membrane

\section{Introduction}

Risperidone, 4-[2-[4-(6-fluorobenzo[d]isoxazol-3-yl)1-piperidyl] ethyl]-3-methyl-2,6-diazabicyclo[4.4.0]deca-1,3-dien5-one, is a widely used antipsychotic drug $[1,2]$. Risperidone changes the effects of certain chemicals in brain, and it is used in the treatment of schizophrenia and bipolar disorder (manic depressive disorder). Risperidone is also used to treat symptoms of sourness and short temper in autistic children [1]. Dose adjustment is of quite important in the use of risperidone $[1,3]$. Therefore, drug monitoring in during risperidone treatment is essential to avoid serious side effects, such as extrapyramidal symptoms (in high doses), hyperprolactinemia, weight gain, headaches, and dizziness [1-5]. Numerous studies conducted on the analysis of different matrices and some determination methods have been developed [1, 311]. These are UV spectroscopy, high performance liquid chromatography, mass spectroscopy and some electrochemical means. However, all developed methods based on LC are expensive, time consuming due to pre-and post-column reaction, and also not very selective or sensitive.

The potentiometric method has many advantages compared to other widely used instrumental methods. Potentiometric methods do not cause degradation of the sample, and only contaminate the sample to a negligible extent. In addition, the response time of the electrode is relatively short. Therefore these methods are used for the determination of clinical and industrial samples. The electrodes are also used as detectors in chromatographic and flow path-injection analysis. In this study, preparation of micro sized composite risperidone-sensitive sensor, development of prepared composite risperidone-sensitive electrodes was aimed. For this purpose, risperidone-sensitive sensor membrane was prepared by coating the composite mixture on the surface of contact transducer in solid state. The potentiometric performances of the risperidone-sensitive sensor namely, the selectivity constant, liner domain, detection limit, response time, $\mathrm{pH}$ working range (domain), repeatability, lifetime, and time dependent 
potential decay were determined using a computer controlled measurement system in static conditions.

\section{Materials and Methods}

Reagents and solutions

Risperidone working-standard powder with 99.98\% purity was obtained from Fluka (Bucks, Switzerland). High molecular weight poly(vinylchloride) (PVC), tetrahydrofuran (THF), sodium tetraphenyl borate (NaTPB), o-nitro phenyloctyl ether (NPOE), dibutylphthalate (DBP), bis(2- Ethylhexyl) sbacate (BEHS), and graphite were purchased from Fluka (Switzerland. Phenol red (PR) and bromophenol blue (BPB) were purchased from Merck. All standard solutions and eluents were prepared from their analytical reagent grade chemicals in deionized water, and then diluted to the desired concentrations.

Separately $1.0 \mathrm{~g}$ of BPB and PR $(1.0 \%)$ were dissolved in $10 \mathrm{~mL}$ of acetone and made up to $100 \mathrm{~mL}$ with acetone. A stock standard RSP solution $(0.10 \mathrm{~mol} / \mathrm{L})$ was prepared by dissolving $820.96 \mathrm{mg}$ of the pure drug in $20 \mathrm{~mL}$ dichloromethane. Working solutions $\left(1 \times 10^{-1}-1 \times 10^{-5} \mathrm{~mol} / \mathrm{L}\right)$ were prepared as required by dilution.

\section{Method}

The proposed methods are based on the formation of ion-pair complexes between RSP of phenol red (PR) (ionophore a) and bromophenol blue (BPB) (ionophore b) [7]. These interactions were expected to cause ionophore like attitude in the compounds of phenol red and bromophenol blue. Therefore these compounds were used in the construction of risperidoneselective sensor separately as ionophore. A second path between RSP - PR (ionophore c) and RSP - BPB (ionophore $d$ ) ion-pair complexes is created. These complexes were used in the preparation of risperidone-selective sensors as an ionophore.

Formation of risperidone - Phenol red (RSP - PR) and risperidone - Bromo phenol blue (RSP - BPB) ion-pair complexes

The basic nature of the drug RSP utilizes the anionic dye to form an ion-pair complex. Due to the resonance effect, the protonation of benzisoxazole ring and in pyrimidin-4-one is very difficult. Thus, there is only one site which is susceptible to protonation, and that is the nitrogen in the piperidine ring [7, 12]. Among the two tautomers present in equilibrium, a quinoid group must predominate due to the strong acidic nature of the sulfonic group. Protonated RSP forms ion-pairs with the dyes BPB and PR in 1:1 ratio [7]. The possible reaction pathways are depicted in Figures 1 and 2 . The RSP solution prepared by dissolving in dichloromethane was transferred slowly and separately to the PR and BPR solutions and mixed well. The solutions were filtered and left to crystallize at room temperature.

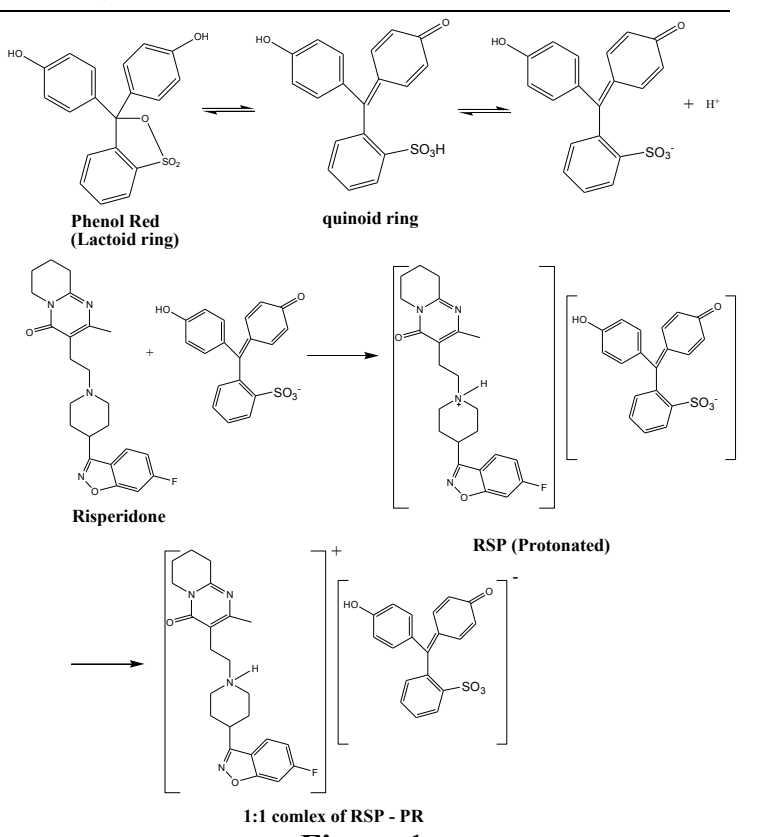

Figure 1.

Possible reaction pathway for the formation of RSP - PR ion-pair complex [7]
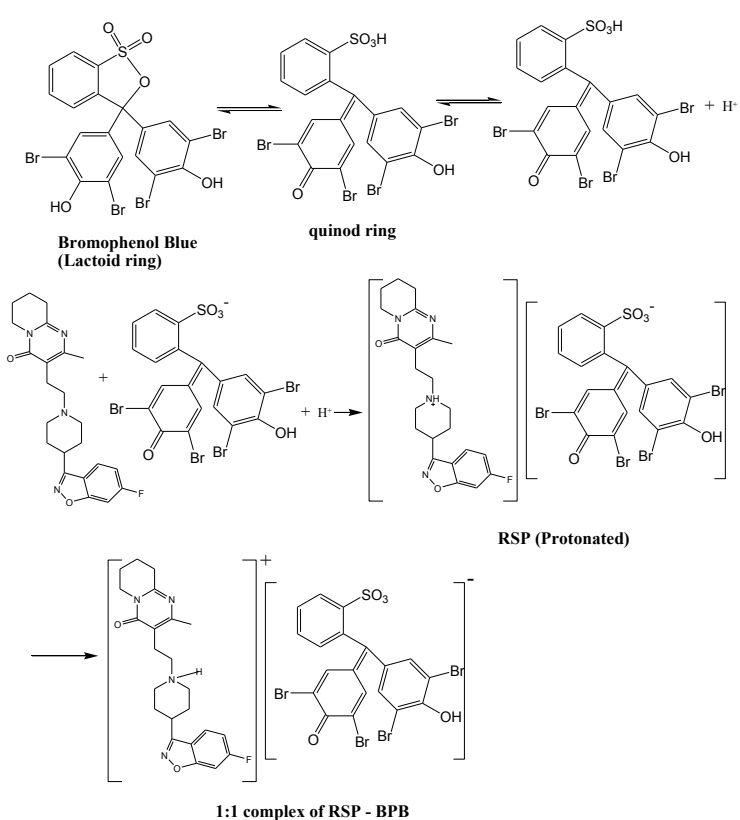

Figure 2.

Possible reaction pathway for the formation of RSP - PR ion-pair complex [7]

Preparation of the electrodes and measurement procedure

Manufacturing an electrode is generally a two-step process. The first step is the preparation of the surface to be coated with a membrane which brings solid contact $[13,14]$. In this study, solid-contact composition was made from graphite $50 \%(\mathrm{w} / \mathrm{w})$, epoxy resin $35 \%$ $(\mathrm{w} / \mathrm{w})$, and hardener $15 \%(\mathrm{w} / \mathrm{w})$. Following dissolving in THF, it was stirred thoroughly until the solution reached a suitable viscosity. A copper wire (about 0.5 - $1 \mathrm{~mm}$ thick, 5 - $15 \mathrm{~cm}$ long) was coated over 4 - 5 
FARMACIA, 2018, Vol. 66, 6

times dipped into the mixture and it was allowed to stand at room temperature overnight. The second step is to apply the membrane mixture to a solid state contact surface. In the coating process, the membrane composition was comprised of the active ingredient (ionophore) $1.5 \%-5 \%(\mathrm{w} / \mathrm{w})$, DBP as a plasticizer $(67.0 \%, \mathrm{w} / \mathrm{w}), \mathrm{PVC}(30 \%, \mathrm{w} / \mathrm{w})$ and NaTPB $(0.5-1 \%$, $\mathrm{w} / \mathrm{w}$ ) and was dissolved in $5 \mathrm{~mL}$ of THF. Including mixtures were dissolved in THF and allowed to stand until the proper viscosity was reached. Then the prepared membrane cocktail was applied to the solidstate contact surface, which was coated at approximatively $0.1 \mu \mathrm{m}$. Next, the prepared sensors were allowed to dry for 3 - 4 hours.

Selectivity, response time, limit of detection, and static media performances of such behaviour of the potentiometric sensors at composite structure made all solid state contact PVC membrane structure have been examined at the optimum room conditions. Potentiometric measurement cells are displayed schematically as follows:

Conducting wire | Solid-state contact | RSP-sensitive membrane | Test solution $\|$ External reference electrode

\section{Results and Discussion}

Investigation of the optimum membrane composition Ionophore, plasticizer, ionizer, PVC ratios, plasticizer and ionizer species in PVC membrane selective electrodes are important factors that determine the potentiometric performance characteristics of the electrode. To determine the optimum membrane chemical composition of solid-state contact PVC composite membrane, the potentiometric behaviour of electrodes was investigated by changing the percent ratio of each component. The obtained percent membrane chemical composition ranges with the best performance are provided in Table I.

Table I

The chemical composition ratio of the composite membrane electrodes

\begin{tabular}{|l|c|}
\hline \multicolumn{1}{|c|}{ Components \% } & \multirow{2}{*}{67} \\
\cline { 1 - 1 } Nitrophenyl octyl ether & \\
\cline { 1 - 1 } Dibutyl phthalate & \multirow{2}{*}{30} \\
\cline { 1 - 1 } Bis ethylhexyl sebacate & \multirow{2}{*}{2.5} \\
\cline { 1 - 1 } PVC & \\
\cline { 1 - 1 } Ionophore - a & \\
\hline Ionophore - b & 0.5 \\
\hline Ionophore - c & \\
\cline { 1 - 1 } Ionophore - d & \\
\cline { 1 - 1 } NaTPB &
\end{tabular}

Preparing the electrode membrane cocktails was found to exhibit the best potentiometric behaviour of plasticizers while using separately each of the three different plasticizers. These measurements also show the best potentiometric behaviour showed by dibutylphthalate plasticizer. Figure 3 displays the influence of the plasticizer on the electrode's potentiometric behaviour.

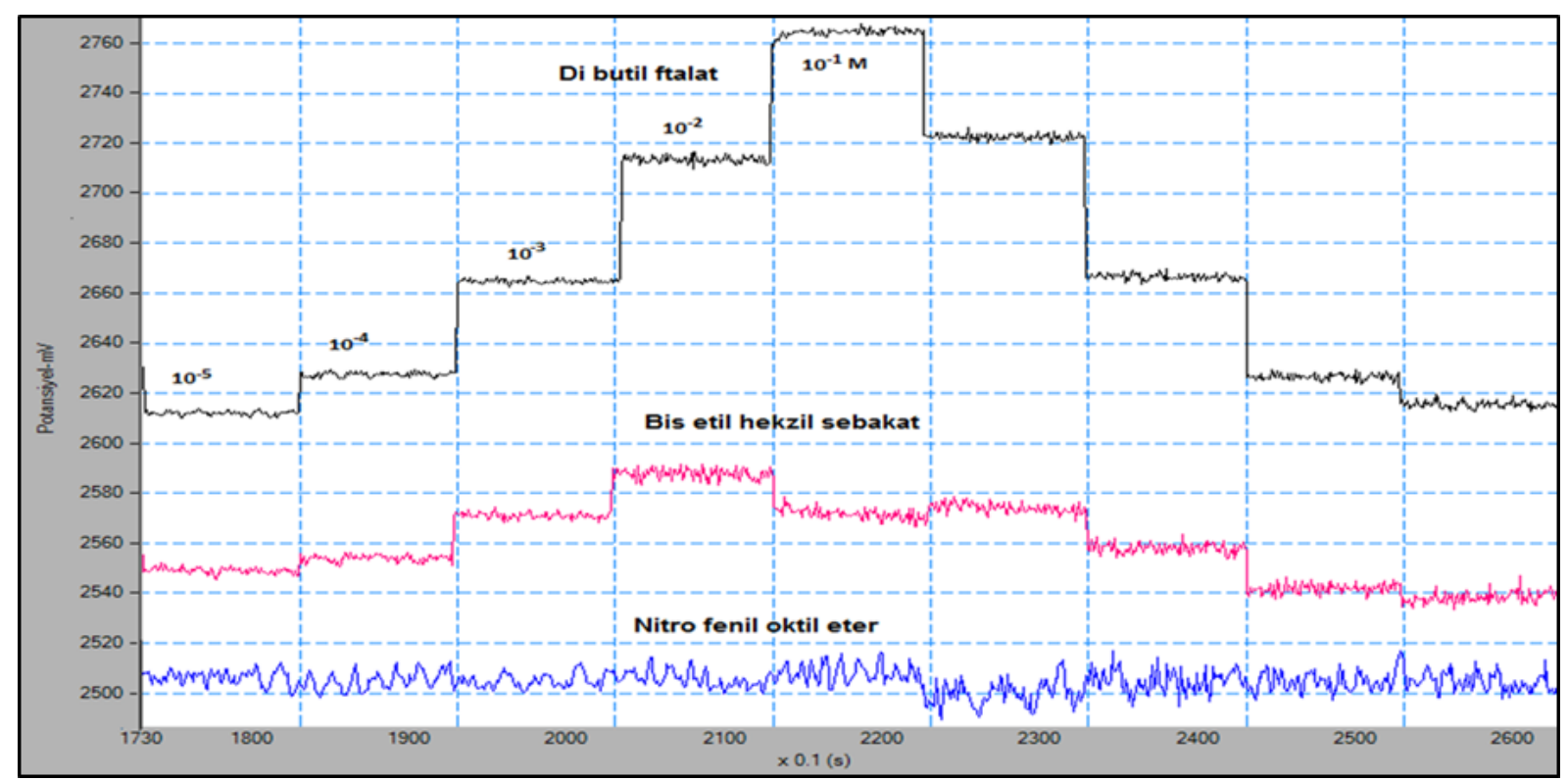

Figure 3.

Effect of plasticizer on potential with respect to RSP concentrations

To determine the ionophore percentage, the membrane composition was prepared in ranges between $5 \%$ and $1.5 \%$. By measuring $10^{-1} \mathrm{~mol} / \mathrm{L}$ risperidone solutions, the highest potential behaviour showing membrane rates were determined. The highest potential value was obtained with the membrane compositions containing $2.5 \%$ ionophore (Figure 4 ). 


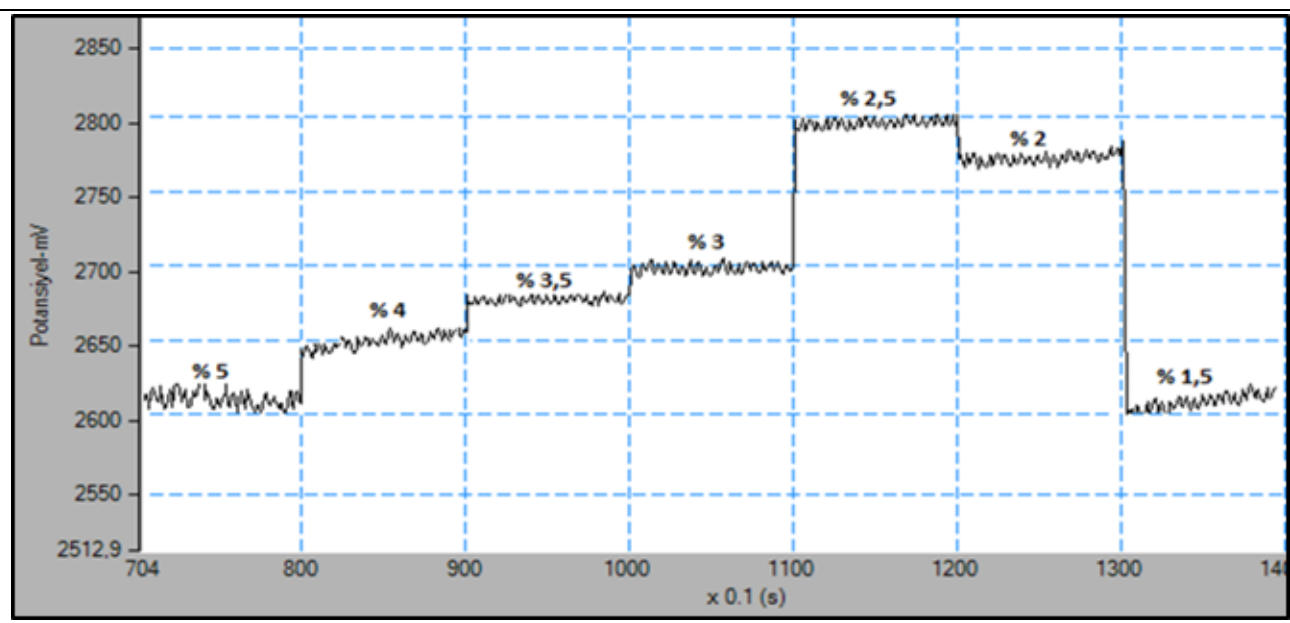

Figure 4.

Potentiometric values from membrane electrodes with variety of ionophore-c compositions in $10^{-1} \mathrm{~mol} / \mathrm{L}$ solution of RSP

Using this percentage, risperidone-sensitive the composite PVC membrane electrodes were prepared. Potentiometric performance of risperidone - selective electrode

The composite solid-state risperidone-selective electrodes were prepared and allowed to conditioning for $1.5-2.0$ hours in the risperidone solution before tested (Table II). Special attention was paid to the washing of the electrode with deionized water between measurements.

When examining potential changes, the sensor prepared by ionophore-c component showed a better exchange exhibit than others (Figure 5).

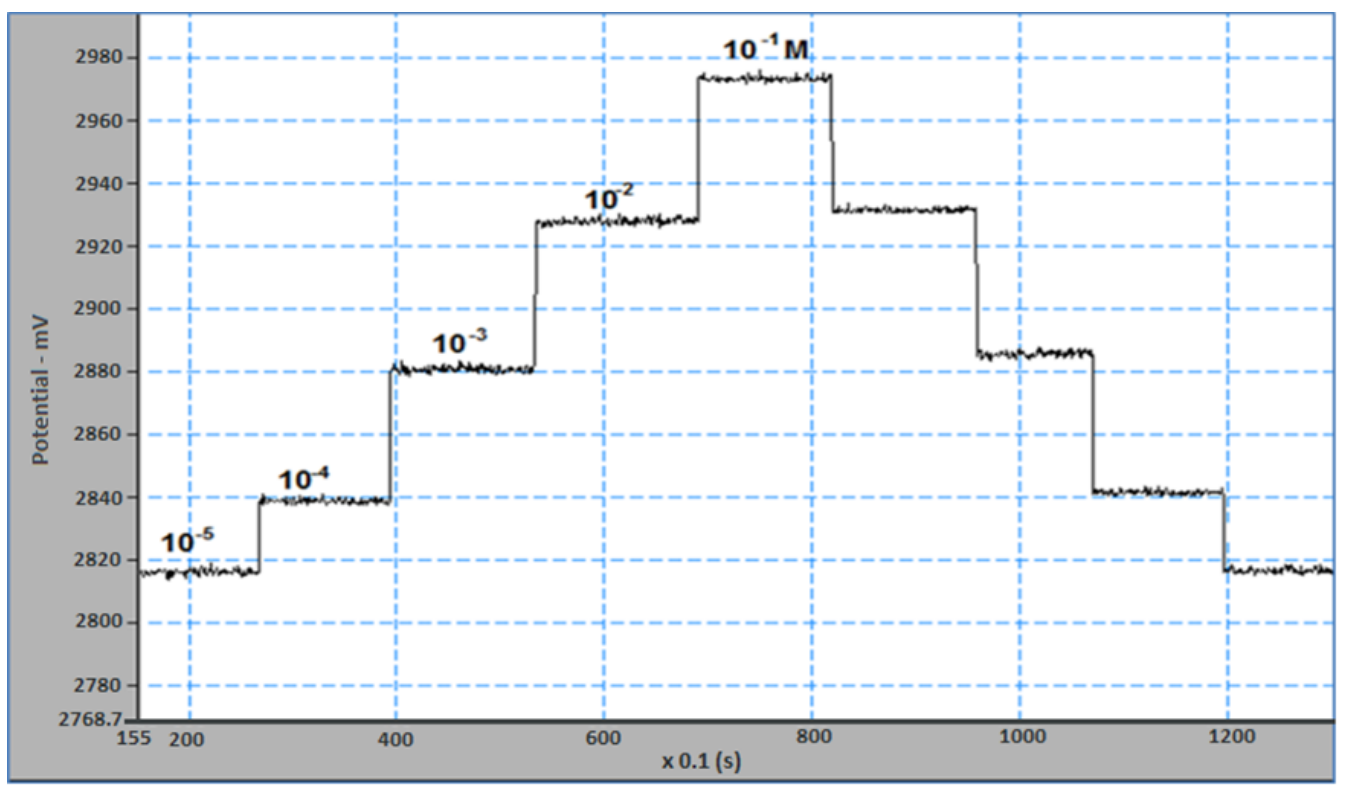

Figure 5.

Potentiometric values of RSP-sensitive electrode with respect to the RSP concentration

Table II

Potential values obtained against the $10^{-1}-10^{-5} \mathrm{~mol} / \mathrm{L}$ RSP concentration change of the electrodes prepared in different compositions $(\mathrm{mV}),(\mathrm{n}=3)$

\begin{tabular}{|c|c|c|c|c|}
\hline$-\log \mathbf{C}(\mathbf{m o l} / \mathbf{L})$ & Ionophore-a & Ionophore-b & Ionophore-c & Ionophore-d \\
\hline 1 & $2792.6 \pm 1.2$ & $2834.4 \pm 2.6$ & $2974.5 \pm 1.2$ & $2871.3 \pm 3.1$ \\
\hline 2 & $2713.4 \pm 1.6$ & $2794.4 \pm 2.9$ & $2927.3 \pm 1.3$ & $2811.7 \pm 3.7$ \\
\hline 3 & $2701.4 \pm 1.8$ & $2782.8 \pm 3.05$ & $2881.7 \pm 2.7$ & $2798.3 \pm 5.6$ \\
\hline 4 & $2687.1 \pm 1.9$ & $2773.4 \pm 5.5$ & $2839.6 \pm 3.1$ & $2788.6 \pm 4.3$ \\
\hline 5 & $2671.9 \pm 2.1$ & $2763.5 \pm 7.4$ & $2817.8 \pm 3.6$ & $2777.1 \pm 6.2$ \\
\hline
\end{tabular}


FARMACIA, 2018, Vol. 66, 6

By analysing the noise of membrane electrodes containing ionophore-b and ionophore-d, there was observed that RSP - PR and RSP - BPD were used as ionophore membrane electrodes. High levels of noise reduced the activity of the electrode. The reason for this image formation, although not very significant, may be associated with the ionophore activity. Without an effective ionophore, the effects of other components of the membrane can be in the forefront. It may also affect the measurement of the characteristics of the species in the solution.

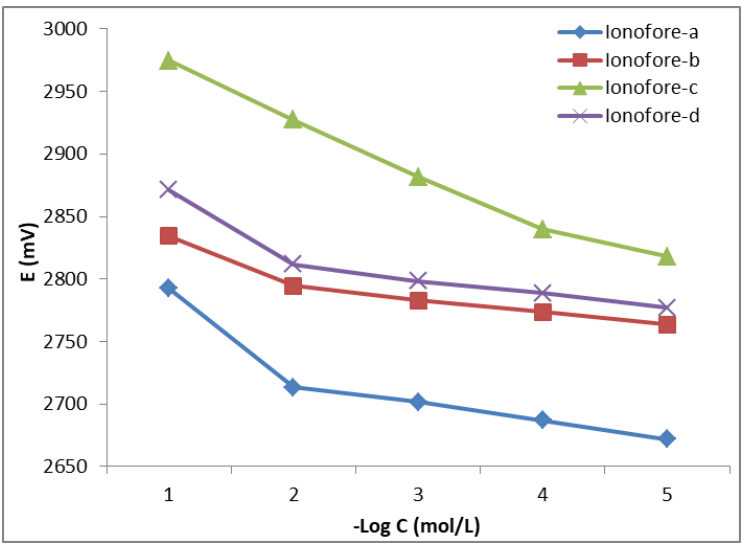

Figure 6.

Potentiometric responses of all solid-state PVC membrane RSP-sensitive electrodes

When examining the potential change measured against changes in the concentrations of risperidone compared to others of the membrane, electrodes containing ionophore-c proved to exhibit a smoother and a good change (Figure 6). This electrode's linear gradient is the equation of $y=-40.11 E+3008.5$ with a correlation coefficient 0.9848 of $r^{2}$ value and then others have been found to exhibit a better linearity. The resulting potential change values indicate conformity with the Nernst equation. A calibration curve was created by passing graphics of potential change measured against changes in the $10^{-1}-10^{-5} \mathrm{~mol} / \mathrm{L}$ concentrations of risperidone solution. The linear response of the electrode appears in the calibration curve.

When the potential measurement moved from a high concentration to a low concentration, it seemed to exhibit a better linearity of the electrode. However, the transition to a high concentration from a low concentration showed less potential changes and a prolonged response time. Generally, an ion-selective electrode may be common across this situation. However, a faster response time in the direction of increasing concentration and reproducible results can be obtained if the electrode is washed with large quantities of deionized water.

The response time of risperidone - selective electrode The response time ( $\mathrm{t} 95 \%$ ) is known as the time period for the presented potential of electrode to reach equilibrium with the sensible part of the membrane. The risperidone concentration was rapidly increased from $10^{-5}$ to $10^{-1} \mathrm{~mol} / \mathrm{L}$ and the $195 \%$ values were measured. The response time obtained was always less than $10 \mathrm{~s}$ (Figure 7).

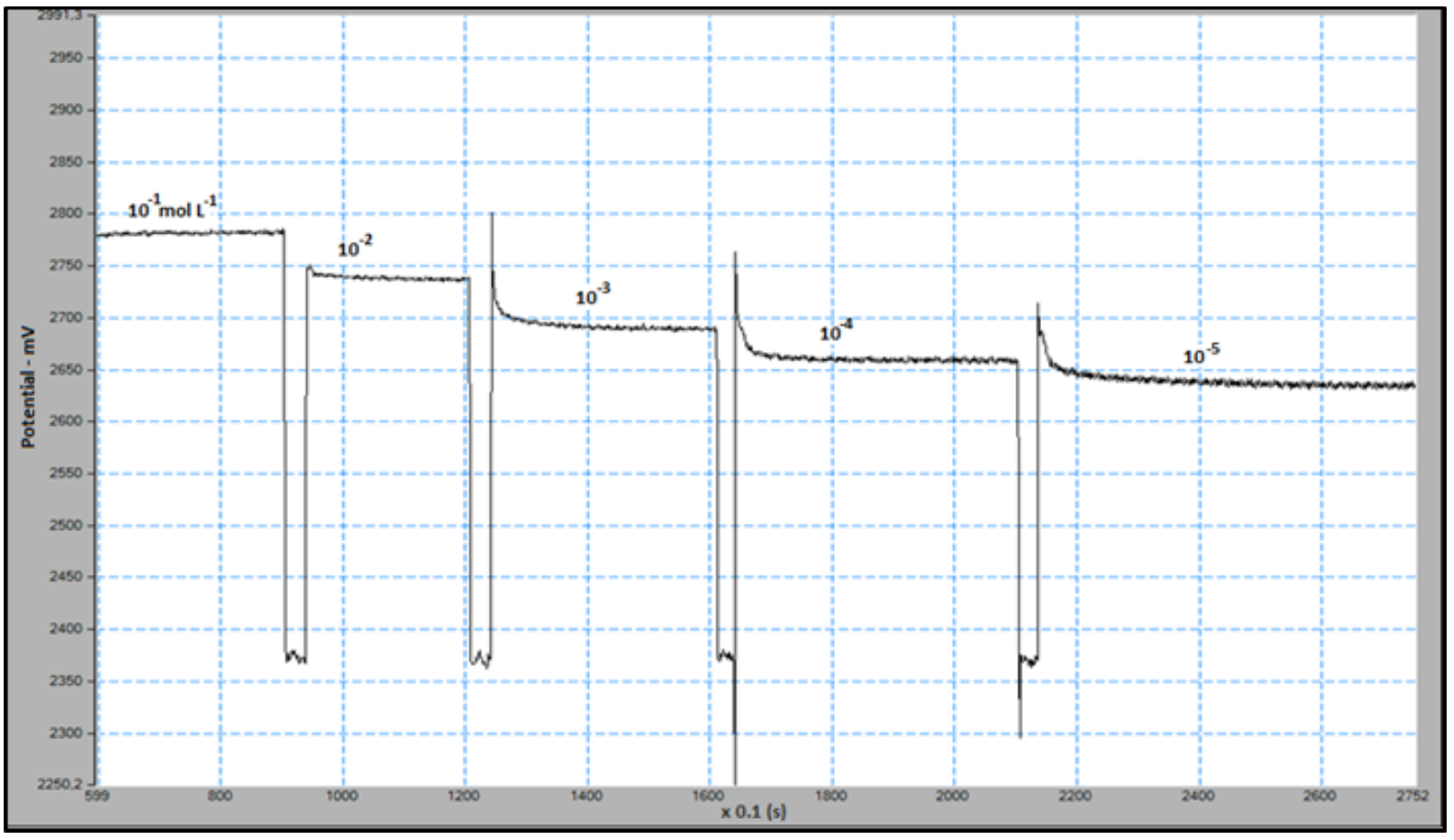

Figure 7.

The response time of all solid-state PVC membrane risperidone - sensitive electrode 
FARMACIA, 2018, Vol. 66, 6

The selectivity of risperidone - selective electrode The all solid-state contact risperidone-selective membrane sensor, together with other constituents, demonstrated very good selectivity towards risperidone over other ions tested. The potentiometric selectivity coefficients of all solid-state risperidone - selective sensors were evaluated by the separate solutions method according to the IUPAC recommendation [15]. Sensitivity is reduced to the strain to be measured of the electrode, if the selectivity coefficient $(\mathrm{k})$ is increased. The calculated selectivity coefficients are given in Table III. There was a noticeable decrease in the selectivity for risperidone relative to other metal ions (Figure 8). As seen in Figure 8, it is quite obvious that the proposed risperidone-selective sensor is highly selective with respect to interfering ions.

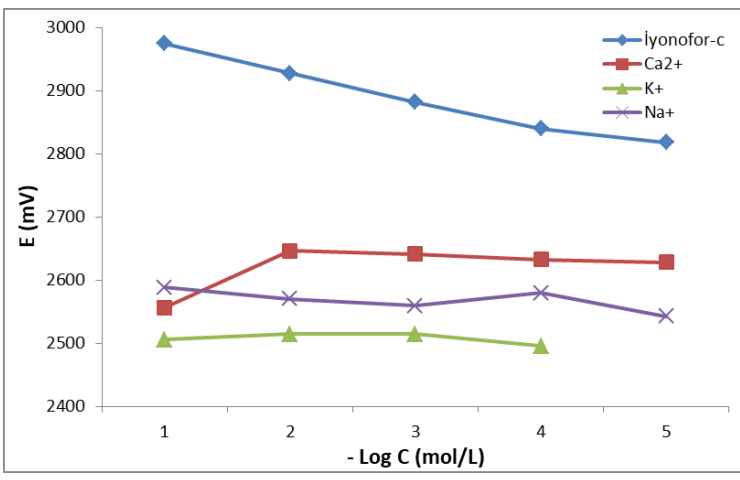

Figure 8.

Potential curves of all solid-state PVC membrane RSP-sensitive electrode and interfering ions

Table III

Selectivity coefficients values of RSP-selective sensors

\begin{tabular}{|c|c|c|c|}
\hline & Interfering & $\left(\right.$ Logk $\left.k_{\text {risperidone,interfering }}^{\text {pot }}\right)$ & $\left(\boldsymbol{k}_{\text {risperidone,interfering }}^{\text {pot }}\right)$ \\
\hline \multirow{3}{*}{$\begin{array}{l}\text { Selectivity coefficient } \\
\left(\boldsymbol{k}_{\text {risperidone,interfering }}^{\text {pot }}\right)\end{array}$} & $\mathrm{Na}^{+}$ & -7.0686 & $8.54 \times 10^{-8}$ \\
\hline & $\mathrm{K}^{+}$ & -8.9298 & $1.18 \times 10^{-9}$ \\
\hline & $\mathrm{Ca}^{2+}$ & -14.1346 & $7.34 \times 10^{-15}$ \\
\hline
\end{tabular}

The reusability of risperidone - selective electrode The all-solid-state PVC membrane of the risperidone selective electrode showed that the results can easily be reproduced. Figure 9 depicts the reusability of the sensor for $10^{-2}, 10^{-3}$, and $10^{-4} \mathrm{~mol} / \mathrm{L}$ risperidone concentrations.

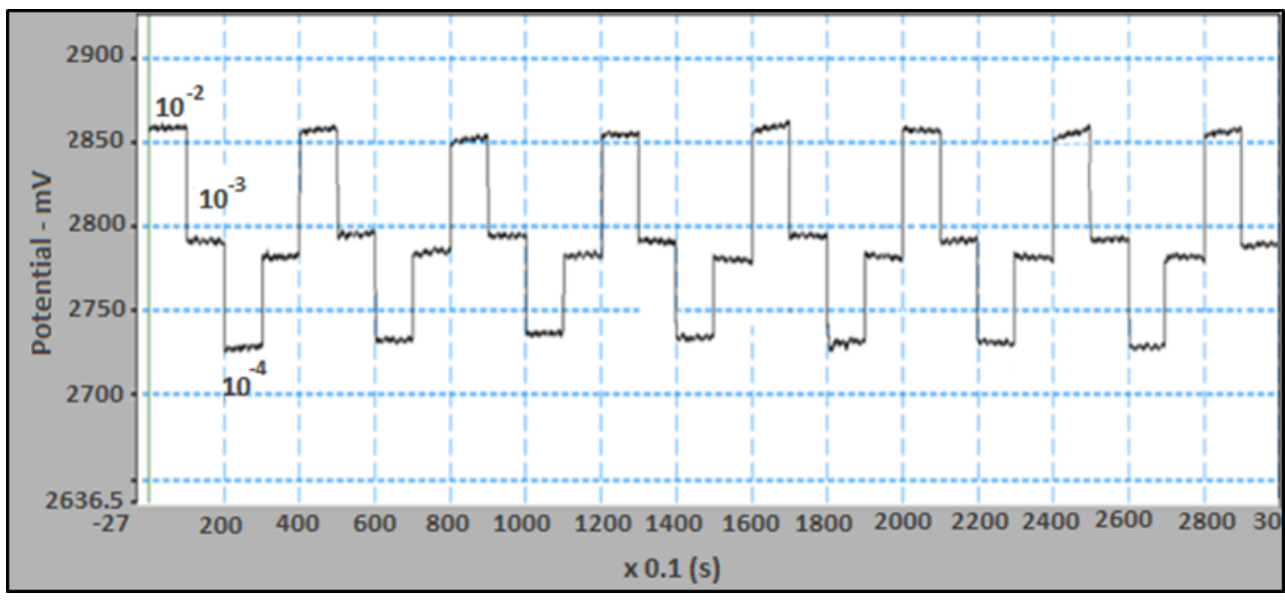

Figure 9.

The reusability of all solid-state PVC membrane RSP - sensitive electrode

The $\mathrm{pH}$ dependence of risperidone - selective electrode The $\mathrm{pH}$ dependence of the electrode response was examined by using in $\mathrm{pH} 2-12$ solution adjusted with hydrochloric acid and sodium hydroxide. The all-solid-state PVC membrane risperidone - selective electrode showed a potential change against the risperidone concentration of $10^{-3} \mathrm{~mol} / \mathrm{L}$ in acidic and basic mediums. The potential remained unaffected over a $\mathrm{pH}$ range $4.0-12$.

The lifetime of risperidone - selective electrode In an investigation about long term storage stability of the risperidone - selective membrane sensor, the sensor was kept dry at $4-6^{\circ} \mathrm{C}$, the calibration curve was recorded each day, and the potentials were measured. The sensor demonstrated good storage stability with a slope of about $14 \mathrm{mV}$ reduction for at least two months to standard risperidone concentration change.

\section{Conclusions}

A novel potentiometric sensor based on all solid state contact was developed for the fast and simple analysis of risperidone. A composite risperidonesensitive sensor could easily be obtained with low costs. The sensor has ionophore c, DBP as a plasticizer and NaTPB as an anion excluder in PVC components. 
The response time of risperidone-selective sensor is considerable with $10 \mathrm{~s}$ and it exhibits Nernstian behaviour throughout the working concentration range. The risperidone-selective sensor exhibits a good working $\mathrm{pH}$ range. Additionally, risperidone-sensitive sensors can be miniaturized and used remotely. The developed sensor is suitable for the production of a detector cell with micro litre dead volume and therefore suitable to be used in chromatography systems. Therefore the expensive measurements could be achieved at low costs. Additionally, we believe this work imparts an important contribution to the present literature.

\section{Acknowledgement}

The study was supported by The Scientific and Technological Research Council of Turkey, TUBITAK, project no. $114 \mathrm{Z} 033$.

\section{References}

1. Saracino MA, Palma A, Boncompagni G, Raggi MA, Analysis of risperidone and its metabolite in plasma and saliva by LC with coulometric detection and a novel MEPS procedure. Talanta, 2010; 81: 1547-1553.

2. Ansermot N, Brawand-Amey M, Kottelat AÜ, Eap $\mathrm{CE}$, Fast quantification of ten psychotropic drugs and metabolites in human plasma by ultra-high performance liquid chromatography tandem mass spectrometry for therapeutic drug monitoring. J Chromatogr A, 2013; 1292: 160-172.

3. Nicolae AC, Arsene AL, Vuță V, Popa DE, Sîrbu CA, Burcea Dragomiroiu GTA, Dumitrescu IB, Velescu BS, Gofiță E, Drăgoi CM, In vitro p-Gp expression after administration of CNS active drugs. Farmacia, 2016; 64(6): 844-850.

4. Bocato MZ, Simões RA, Calixto LA, Gaitani CM, Pupo MT, Oliveira ARM, Solid phase microextraction and $\mathrm{LC}-\mathrm{MS} / \mathrm{MS}$ for the determination of paliperidone after stereo selective fungal biotransformation of risperidone. Analytica Chim Acta, 2012; 742: 80-89.

5. Mandrioli R, Mercolini L, Boncompagni G, Raggi MA, Analysis of risperidone and 9-hydroxyrisperidone in human plasma, urine and saliva by MEPS-LC-UV. J Chromatogr B, 2011; 879: 167-173.

6. Avenoso A, Facciola G, Salemı M, Spina E, Determination of risperidone and its major metabolite 9-hydroxyrisperidone in human plasma by reversedphase liquid chromatography with ultraviolet detection. J Chromatogr B, 2000; 746; 173-181.

7. Deepakumarı HN, Mallegowda SM, Vinay KB, Simple and extraction-free spectrophotometric methods for risperidone in pure form and in dosage forms. Chem Ind Chem Engin Quarterly, 2013; 19(1): 121-128.

8. Afkhami A, Ghaedi H, Multiwalled carbon nanotube paste electrode as an easy, inexpensive and highly selective sensor for voltammetric determination of Risperidone. Analyt Meth., 2012; 4: 1415-1420.

9. Locatelli İ, Mrhar A, Grabnar İ, Simultaneous determination of risperidone and 9-hydroxyrisperidone enantiomers in human blood plasma by liquid chromatography with electrochemical detection. $J$ Pharm Biomed Anal., 2009; 50: 905-910.

10. Meulder M, Remmerie BMM, Vries R, Sips LLA, Boom S, Hooijschuur EWİ, Merbel NC, Timmerman PMMBL, Validated LC-MS/MS methods for the determination of risperidone and the enantiomers of 9-hydroxyrisperidone in human plasma and urine. $J$ Chromatogr B, 2008; 870: 8-16.

11. Cioates Negut $C$, Stefan-van Staden RI, Ungureanu EM, Udeanu DI, Stochastic sensors designed for assessment of biomarkers specific to obesity, Journal of Pharmaceutical and Biomedical Analysis, 2016; 128: 280-285.

12. Harikrishna K, Nagaralli BS, Seetharamappa J, Extractive Spectrophotometric Determination of Sildenafil Citrate (Viagra) in Pure and Pharmaceutical Formulations. J Food Drug Anal., 2008; 16: 11-17.

13. Isildak I, Yolcu M, Isildak O, Demirel N, Topal G, All-solid-state PVC membrane $\mathrm{Ag}^{+}$-selective electrodes based on diaza-18-crown-6 compounds. Microchim Acta, 2004; 144(1-3): 177-181.

14. Isildak O, Durgun D, All-Solid-State PVC Membrane Fe (III) Selective Electrode based on 2-Hydroxymethyl-15-crown-5. Int J Engin App Sci., 2015; 2(4): $1-5$.

15. Umezawa Y, Buhlmann P, Umezawa K, Tohda K, Amemiya S, Potentiometric selectivity coefficients of ion-selective electrodes. Pure App Chem., 2000; 72(10): 1851-2082. 